\title{
Sustainable development: impossible without women's development
}

\author{
S. Zahedi \\ Allameh Tabataba'i University, Iran
}

\begin{abstract}
Two decades ago, in 1987, the concept of sustainable development was expressed in the Brundtland Commission Report. The follow-up global conferences in Rio (1992) and in Johannesburg (2002), highlighted the sustainability concept with the major characteristics of ecological sustainability and fair distribution over time and in space. Considering these important issues concerned with accomplishing sustainable development, the author views sustainability from a social perspective and believes that sustainable development is impossible unless gender mainstreaming is embodied in its vision, strategies, policies and programs.

The Fourth World Conference on Women held in Beijing in 1995, identified the major critical areas of concern requiring action by governments and the international community and stressed the need to promote women's status in those major areas. Twelve years after the Beijing Conference, there is still a large gap between what women actually obtained and what was written in the Beijing Platform for Action. There are still very important issues that have not been dealt with properly. It is widely recognized that in order for the world to be able to obtain sustainable development, it is fundamental for all citizens to participate in the development process and this is only possible with the full involvement of women. This means that women's issues must be given priority in national and international arenas. This article will discuss five important issues that deserve prior attention and adequate action for women's development: globalization and women, violence against women, trafficking of women, armed conflicts and the gender digital divide.

The author believes that sustainable development is but a repeated slogan and a dream that will not come true unless it includes women's development in its agenda.
\end{abstract}

Keywords: sustainable development, women development, globalization, violence against women, trafficking, armed conflicts, gender digital divide. 


\section{Introduction}

Two decades ago in 1987, the concept of sustainable development was expressed in the Brundtland Commission Report. The follow-up global conferences in Rio (1992) and in Johannesburg (2002), highlighted the sustainability concept with the major characteristics of ecological sustainability and fair distribution over time and in space. Considering these important issues concerned with accomplishing sustainable development, the author views sustainability from a social perspective and believes that sustainable development is impossible unless gender mainstreaming is embodied in its vision, strategies, policies and programs.

The Fourth World Conference on Women held in Beijing in 1995, identified the major critical areas of concern requiring action by governments and the international community and stressed the need to promote women's status in those major areas. Twelve years after Beijing Conference, there is still a large gap between what women actually obtained and what was written in the Beijing Platform for Action. There are still very important issues that have not been dealt properly. It is widely recognized that in order for the world to be able to obtain sustainable development, it is fundamental for all citizens to participate in the development process and this is only possible with the full involvement of women. This means that women's issues must be given priority in national and international arenas. This article will discuss five important issues that deserve prior attention and adequate action for women's development: globalization and women, violence against women, trafficking of women, armed conflicts, the gender digital divide.

Following is a brief discussion about these issues.

\section{Globalization}

\subsection{Definition}

Globalization is a set of multi-dimensional processes encompassing many arenas of ideology, economy, politics, and culture [1]. In fact, globalization is the rapidly accelerating integration of many local and national economies into a single global market regulated by the World Trade Organization. These developments raise profound questions for humanities in general and for women in particular [2].

The complex and contradictory impacts of globalization on women are as follows:

a) Positive impacts

1. Globalization has enhanced some employment opportunities for women, where previously they had not existed.

2. Globalization raises the number of international organizations that employ many women around the world. According to a report published by the United Nations Center on Transnational Corporations in 1988, international firms employ about two million women in developing countries. Of course it should be noted that these firms often favor 
employing women because they are seen as more efficient and stable than men, and at the same time their wages are lower than those of men and it is easier to hire and lay off women [3]. This is so because women are predominantly in lower-level and lower-paid positions.

3. The migration of women in search of employment opportunities has helped them ease the problem of poverty in many cases and meet the labor needs of a number of countries.

4. Through globalization, women will realize that there are similar questions and challenges faced by their counterparts elsewhere around the world.

5. The idea of women's rights as human rights allowed women across the world to forge common bonds and provides an example of 'globalization from below', rather than being an idea imposed from above. The idea that women's rights are human rights emerged from grassroots activism and illustrates how feminist re-conceptualization of 'universal' rights are compatible with wide local diversity in interpretation and action.

b) Negative impacts

1. Globalization and liberalization strengthen patriarch structures, norms and values, and accelerate barriers to women's economic empowerment [4].

2. Globalization has increased the sexualization of women and many women have been drawn into some aspect of sex work. A vastly expanded global sex trade results in millions of women being employed as sex workers outside their countries of origin.

3. The traditional sexual division of labor has been furthered through new locations and forms of work with conditions of exploitation, and violation of women's rights.

4. Trafficking of women and girls at a speed far greater than had previously existed.

5. High levels of economic and social uncertainty and exposure of women to diverse mechanisms of exploitation.

Although globalization has increased the number of women workers, this increase is not in the core workforce. Women are usually employed in marginalized groups of workers consisting of part-time, temporary, casual, and sub-contracted labor. Gills holds that "much empirical evidence indicate that economic globalization, in particular globalization of production, brings with it further exploitation and impoverishment of women, rather than their empowerment and emancipation" [1].

\subsection{Suggestion}

In order to minimize the threats and negative impacts of globalization, the issue of women's rights should be high on the global human rights agenda. Both national and international bodies should pay more attention to women's issues and commit additional budget and efforts, using a multifaceted approach to minimize the negative impacts of globalization on women. 


\section{Violence}

\subsection{Definition}

Gender-based violence is violence that is directed against a woman because she is a woman.

Violence against women takes different shapes, among those are: domestic battery, honor killings, forced marriage, forced pregnancy, forced sterilization, forced abortion, rape and sexual assault, genital mutilation, trafficking into forced prostitution, sexual abuse in war and post war period by foreign military bases, the torture of women in custody, taking hostages, denying medical care for injuries, degrading treatment and humiliation...

\subsection{Consequences of violence}

Violence has many negative consequences among which are the following:

a) Physical consequences such as: injuries, morbidity, spread of diseases (HIV/AIDS...), mortality.

b) Psychological consequences such as: shame, social stigma, facing rejection, divorce, being declared unfit for marriage.

c) Economic consequences such as: increasing the rate of women absenteeism at work, decreasing productivity, decreasing national income.

d) Social consequences such as: instability, raising the rate of crimes in society, decreasing social capital in community.

Women around the world are routinely subject to violence and unfortunately governments have not been able to handle this problem. Domestic battery is the leading cause of injury for women in many nations of the world, but systemic violence against women has not been recognized internationally as genocide or a crime against humanity [2]. Similarly, the custody rape of women in war has not been recognized as a war crime - it is simply something normal that soldiers do just as the sexual abuse and torture of women in custody is something done normally by men in authority. Crimes such as battery, torture, humiliation, mutilation, ... against any group other than women would be recognized as a civil and political emergency as well as a gross violation of the victims' humanity [5]. The sale of women in marriage is often recognized as slavery, and forced genital surgery on girls and women without their consent has not been seen as torture [2].

Many partners and ex-partners who abuse women maintain that they love them. They physically abuse them because they can. When some men feel angry, frustrated, threatened, jealous, fearful, or demeaned by others, they can take out their feelings on their female partners, because men more often have the greater physical strength, financial clout, and societal power to control their partners. Women, for a variety of reasons, hesitate to report such crimes, and, even if they do, courts are poor at protecting them [6]. While there are some encouraging signs of progress in the development and implementation of new legislation and procedures with respect to violence against women, states are overwhelmingly failing to uphold their international and national obligations to women [7]. 


\subsection{Suggestions}

- The issue of violence against women should be in the focus of the international community and the global human rights agenda, because violence against women is a serious violation of human rights.

- In order to remove the statistical shortage in violence against women, a data bank with codification of gender-based crimes should be established, keeping a record of complaints annually and easing the process of reporting for the victims.

- Endowing judicial mechanisms with a mandate to intervene and to provide protection for victims through proactive policies and effective measures in order to eradicate violence against women.

- A national secretariat should be established to monitor the indices of implementing the measures and oversee the activities of the relevant organizations to safeguard the rights of women and improve women statistics in the country.

- Setting up organizations and telephone numbers to help the victims of violence.

- Launching research projects about the different aspects of violence against women in each country (focusing on the questions: what, why, who, when, where, and how).

\section{Trafficking}

\subsection{Definition}

Trafficking is to trade women and children for the sex trade and other forms of crimes outside their countries of origin.

Many women and girls are lured by false promises of well-paying jobs abroad and then coerced into prostitution, domestic servitude or other types of forced labor.

About 700,000 people, mostly women and children, are subjected to trafficking yearly and, according to the World Bank, most of the women involved are poor and uneducated [8].

In Asia and the Pacific region, more than 30 million children, both boys and girls, have been traded over the last three decades.

\subsection{Suggestions}

- Judiciary systems can play a key role in fighting trafficking in person. This issue should be high on the judiciary priorities in every single country in the world.

- Governments should focus on fighting the sex trade and trafficking in women and children. 
- Women should participate at the national level in policy formulation for fighting trafficking in person. This would ensure better protection of women and children against gender-based crimes.

- Gender and class locate women and children at the bottom of the human rights hierarchy and deny their survival and dignity as human beings. This provides the foundation to be lured by false promises and be subjected to different crimes. National and international cooperation and a multi-dimensional challenge are needed to overcome this global problem.

\section{Armed conflicts}

\subsection{A few facts}

During armed conflicts women play an important role in preserving social order. This role and the suffering they go through are often unrecognized.

In armed conflicts soldiers and paramilitaries terrorize women with rape, sexual and other physical violence, and harassment. These tactics are tools of war, instruments of terror designed to hurt and punish women, wrench communities apart, and force women and girls to flee their homes (Human Rights Watch). Women in Iraq, Congo, Sierra Leon, Rwanda, and Kosovo, Bosnia and Herzegovina have reported brutal rapes, sexual assaults, sexual slavery, and mutilation committed by male combatants. In some cases, perpetrators first raped then killed their victims. Those who survived the attack suffered from psychological trauma, permanent physical injuries, and health risks especially HIV/AIDS.

Often the end of war does not signal the end of violence against women. The women and children living in areas where foreign military bases are present have been and still are exposed to severe cases of rape and other forms of violence by military personnel stationed in Okinawa, Japan and in Korea [9].

The fragility of women is discarded during war-time. Should the need arise; women fulfil any of the roles required of them [10].

Women do heavy-duty physical labor; engaging in agricultural activities while men are at the battle front. As peace returns, women are relegated to the domestic front as men want their jobs back.

Women, especially poor women, bear a disproportionately heavy share of the burdens imposed by war and militarism. This is partly because an ever-increasing proportion of the casualties of war are comprised of civilians rather than soldiers [2]. In World War I, 20\% of the casualties were civilians. In World War II, 50\%, and in the Vietnam War, 70\% of the casualties were civilians. In today's war $90 \%$ of the casualties are civilians. The combatants in war are predominantly male, but the vulnerable civilians are predominantly women and children. According to statistics of the United Nations High Commissioner for Refugees, in the world today, there are an estimated 21.4 million refugees [11]. Women and children constitute $80 \%$ of the millions of refugees dislocated by war [2]. 
Militarism is the world's major polluter of the environment, from which women suffer disproportionately. When tax revenues are allocated to military spending, rather than to social services (health, sanitation, education, agriculture...), poor women suffer most.

\subsection{Suggestions}

Armed conflict and militarism locate women at the forefront of the casualties. Thus they deserve to participate in the decision-making process, and they should attend and present their views at the formal peace negotiating tables.

Governments should provide the necessary foundations to ensure gender sensitive justice. National governments and international bodies should address the specific needs and concerns of women refugees (assistance, training, and etc.).

\section{Gender digital divide}

\subsection{Definition}

The under-representation of women in terms of access to information and communication technologies (ICTs) and their low number in the computer communications technology and network.

New communication technologies, when democratically employed, constitute powerful instruments for socializing information and the fuller participation of women in all spheres of activity. Nonetheless, access to these technologies is highly unequal in different geographic regions and social groups. This inequality contributes to the increasing the gap between those who have access to abundant information resources and those who are deprived of this access, thus reinforcing the marginalization that already exists in terms of development and technical resources [12].

Removing the digital divide will lead to economic and social empowerment for a vast number of young women who would have remained unemployed. Gender-sensitive ICT training programs are very important in a knowledge-based and Internet economy. This would increase females' access to career opportunities.

Women face different obstacles in using ICTs, among which are the followings: language barriers, educational shortcomings, low access to training and technical assistance, social and cultural barriers, financial and technological shortages.

\subsection{Suggestions}

- Governments should promote the access of women to electronic networks and communication technologies through:

1. raising awareness among women about the advantages of these technologies 
2. allocating the necessary funds for providing IT training to women

3. reducing cost barriers for women to access ICTs

4. offering infrastructural facilities for developing data banks, on-line information services, and Internet resources

5. Offering all-female courses, preferably taught by female instructors....

- Four thresholds must be overcome [13]

1. Access: Creative strategies are needed to bring access to infrastructure to poor rural and under-served areas.

2. Accessibility: Women need to be ensured of easy, safe and affordable access to ICTs.

3. Usability: Illiteracy presents a problem for women in using many ICTs. Three levels of literacy are often required: fundamental literacy, literacy in Internet language and computer literacy. A strong commitment by the community and state is necessary to overcome these problems.

4. Utility: The content of ICTs must be compelling and useful to women. This requires local content, targeted training programs and making sure that women are also content producers.

- ICTs are very helpful in gathering data on trafficking, informing the public about the trafficking, rescuing the trafficked women, and rehabilitating those who are returned home. ICTs could be a powerful tool for prevention, and protection of the victims, and also could help with investigations [14]. Governments can promote the use of IT as a means to control the trafficking of women and girls.

- Governments should launch an official website containing women's issues, statistics in different aspects of women's lives... and upgrade this website at very regular intervals.

- The UN and its agencies and aid organizations should assign budgets to assist these programs in general and to promote gender-sensitive training courses and materials.

- Both national and international institutions should cooperate in solving the digital divide, this means that: Government support is very necessary, the private sector can be part of this strategic intervention, and international agencies should offer support to bridge the gap between the depressed and well off regions concerning access to ICTs.

\section{Conclusions}

In this article the links between sustainable development and women's development has been particularly emphasized. The author believes that sustainable development is but a repeated slogan and a dream that will not come 
true unless it includes women's development in its agenda. Throughout history women have suffered considerably and now it is time to stop the trend.

National governments and international bodies should address the specific needs and concerns of women and put their issues in the focus of the international community. Women's rights should be high on the global human rights agenda because the pre-requisite of sustainable development is women's development.

\section{References}

[1] Gills, D.S., Economic globalization and women in Asia: Challenges and responses, London: Routledge, UNESCAP, 2002.

[2] Jaggar, A.M., Is globalization good for women? "Comparative Literature", Eugene: Fall, Vol. 53, Iss. 4, 2001.

[3] Mendenhall, M., \& Punnett, B., \& Ricks D., Global Management, Blackwell Publishers, Cambridge, Massachusetts, USA, 1995.

[4] Marenga, J., Globalization impeding economic empowerment of women, "GUARDIAN", 18, August, 2004.

[5] Women's rights are human rights: Toward a re-vision of human rights, "Human Rights Quarterly", 1990.

[6] Felson, R.B. \& Robinson, G.E., Violence against women/ Dr. Robinson replies, "American Journal of Psychiatry", Vol, 161, Iss, 8, Washington, USA, 2004.

[7] Benninger-Bude, C. \& Bourke-Martignoni, J., Violence against women: Ten reports "Peacework", Cambridge, March, Vol. 31, Iss. 343, 2004.

[8] World Bank Report, Washington D.C., February 26, 2003.

[9] Matsui, Y., Women and armed conflict- Foreign military bases as a source of violence against women, ESCAP High level intergovernmental meeting to review regional implementation of the Beijing Platform for Action, Asian Women's Resource Exchange, 2000.

[10] Haider, R., A perspective in development, gender focus, University Press Limited, Dhaka, Bangladesh, 2000.

[11] UNFPA, Working to empower women, Women and armed conflict, Washington D.C., 2004.

[12] Association for Progressive Communications (APC), Women's Networking Support Programme to the Fourth World Conference on Women, 1995.

[13] Roseman, W., Gender and the digital divide, Seminar Series \#5, The World Bank Group, March 22, Washington D.C., 2001.

[14] Harendra de Silva, Information and communication technology: A powerful tool to fight against trafficking children, Gender and the digital divide Seminar Series \# 26, 2003. 